\title{
New Methods to Increase the Human Balance and Self Control
}

\author{
Lucian MÂNDREA \\ Politehnica University of Bucharest, Bucharest, Romania \\ mandrea_lucian@hotmail.com,lucian.mandrea@upb.ro \\ Ioan CURTA \\ Transilvania University of Brașov, Brașov, Romania \\ icurta@yahoo.com
}

PICBE | 277

\begin{abstract}
Chaos is unfortunately for humans a characteristic of the modern world. It can be seen at all levels. Each individual can abuse permanently in order to succeed in doing different things. These abuses address the own person but also other persons. The abuses reach then through stress and other ways the level of everybody's health and state. To counterbalance these general tendencies, the authors propose an easy and original method to increase the human general balance. This method is called the method of the wire stretched slowly. It usually increases the general human balance to a level over 99\%, but it also contains the possibility to bring the soul of the physical body to its stable position. The measurements show also that all the other parameters are in the optimal zone. The authors also prove with a second set of measurements made by a Bio Well device that we can control the positions of the main energy centers to increase our own selfcontrol. The Bio Well device uses the gas discharge technique to develop the aura visualization. This time the subject, who is the first author of this article, changed his yang and yin at his own desire. He succeeded in moving the position of his first energy center, the lowest of the seven centers, as he wanted. All the measurements are presented maybe for the first time in the world. They are designed in general to show that we can take more care about us, in terms of energy and health, without seeing to doctors. They lead also to an improved physic and psychic state, wanted by everyone. The control of the position of an energy center refers also to the control of the general equilibrium of the body. Of course, these things are very useful in general behavior leading to business excellence and not only.
\end{abstract}

Keywords: Human body balance, Bio Well Device, The first energy center, Yang, Yin.

\section{Introduction}

The authors present six original measurements performed by means of a Bio Well Device. The problem is of general interest for everybody, because in speaking about the energy and the balance of the human being we speak in fact, also, about health, physical and psychic state and about happiness.

The authors prove with their measurements that special things can be done to improve the performances of every human being. An optimal state can be achieved in terms of emotional pressure or stress, energy, general balance and the organ balance.

A special attention is given in the second part of the article to the first energy center of a human being. At his own will, the first author of the article modifies with precise intention the balance Yin-Yang [https://www.britannica.com/topic/yinyang]. The authors highlighted later how these changes were produced. A final important change in the position of the first energy center was noted with numerical values.

New conclusions are presented at the end in both problems of general interest.

The measurements were made by means of the Bio Well Device (http://www.bio-well.eu/) from the series GDV (Gas Discharge Visualization) invented by professor Konstantin Korotkov, based on the Kirlian effect. These devices are known and utilized because they succeed to highlight in a very short time the modifications 
which occur in the human body. This thing is done by using the fractal mathematical analysis of the photos of each finger of the subject. The ten fingers are stimulated by means of a very short electromagnetic impulse. The emissions of the photons and electrons of each finger are then analyzed. As shown, the results can be seen on a laptop screen, as in Figure 1.
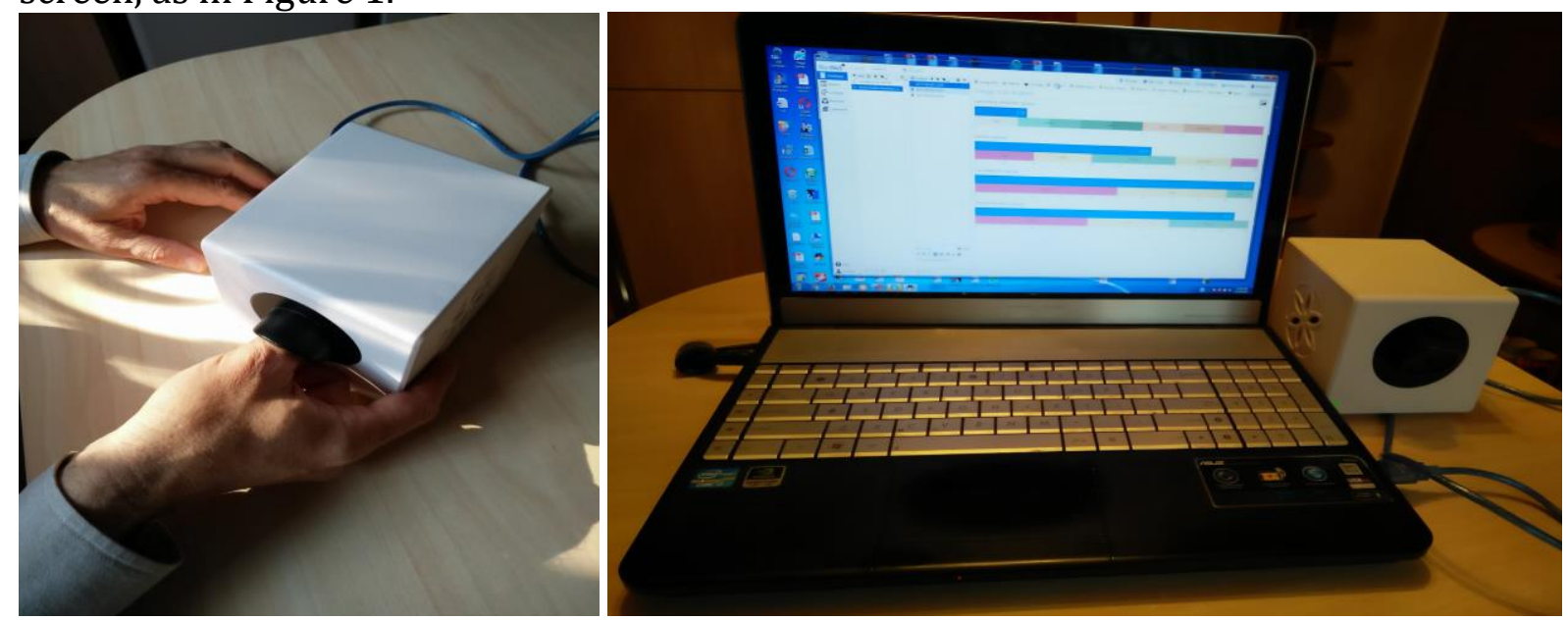

Figure 1.The Bio-Well device and the laptop with the measurement results (The article's first author)

PICBE $\mid 278$

Source: Authors' own research

With the help of the first four measurements the authors present how the energy and balance of the human being can be improved. The first author used a personal and original method called "The method of the stretched wire slowly".

The last two measurements reflect how the yang can grow and the yin can decrease, just at the will of the first author of this article. According to the Indian medicine Ayurveda, we refer to the first medical system used and attested in human history for more than 6000 years [https://ro.wikipedia.org/wiki/Ayurveda], from Wikipedia.

The energy center number 1 is considered the fundamental center of the human energy being [https://en.wikipedia.org/wiki/Muladhara]. It is the lowest center.

The last three measurements were taken into account to present the conclusions of the second part of this article about the energy center number 1.

\section{Measurements and Results}

\section{The first four measurements and results}

These initial four measurements are done to present the increase of the energy and the general balance or the symmetry of the whole body.

The first author of this article applied a personal original method called "The method of the stretched wire slowly" which has immediate good results.

This method consists in the elongation of an imaginary wire with a fixed edge which begins from the upper part of the head, at the middle of the body. The wire must be fired continuously and slowly to the inferior middle part of the body, where the legs begin and it must be linear and vertical at the same time. It is not as easy as it seems, to do this thing. The subject must be patient and perseverant. Maybe at the beginning of the procedure, when somebody learns it, they can succeed in doing this thing only for small parts of the body. This procedure can be compared, for instance, with the slow closure of a zipper. Only that is done from up to down. The procedure must be repeated continuously until the stretched wire begins from the upper part of the head and 
finishes at the bottom of the body, where the energy center 1 is placed. We must specify that we must do this thing from only one movement at the end for the whole distance.

The secret of this procedure is that the first author of the article always sends the soul of his physical body, or yogatma for the yogis, to his equilibrium place. This place corresponds to the second energy center of the body which is placed in the abdomen [Mândrea, 2011], [Mândrea, 2014]. The soul of the physical body can be identified with the orb from photos [Klaus \& Miceal, 2007] and was highlited by the article first author previously in films [Mândrea \& Chirilă, 2017]. That means, if the soul of the physical body is in a higher position, which corresponds to one of the centers number 3 to 7 , then the desired movement of the subject will be downwards, to the center number 2 .

We can add, but the people do not know that the abdominal breath has a similar effect as the soul of the physical body. The air is introduced in the lower parts of the lungs to improve the body oxygenation. But with the descendent movement of the air at every breath, the tendency to displace the soul of the physical body occurs. At the end, it gives us tranquility, but it does not increase the symmetry of the body as our procedure does. We can have a similar effect when we make the cross sign on ourselves. We move our hand from the center number 6 where we put our fingers first, to the center number 2 , where we put the fingers later, making a descendent movement. Therefore, every time we make the cross sign on ourselves, the soul of our physical body will have the tendency to go to the center number 2 where our hand stops a little, giving us the chance to relax. We want to highlight that by our method, having a continuous tendency to obtain a continuous vertical perfect line, a great symmetry or equilibrium of the human being will also be achieved. The authors would like to show, on this occasion, that the fact the own will does changes inside the physical body, can give important results. The changes are reflected in the positions of the seven main energy centers in the human body as can be seen in Figure 2. Such types of measurements can be made by means of the device presented before that is the Bio Well Device [Korotkov, 2002], [Korotkov, 2012], [Mândrea et al., 2015], [Curta, 2014], [Mândrea \& Torp, 2016], [Mândrea \& Curta, 2017].

As the subject's will grows, the major energy centers have the tendency to go to the left as in Figure 2, the so-called the proactive zone of the body, as can be seen in the second and the fourth image. Results are obtained even with small efforts from the author, which the device is able to see.

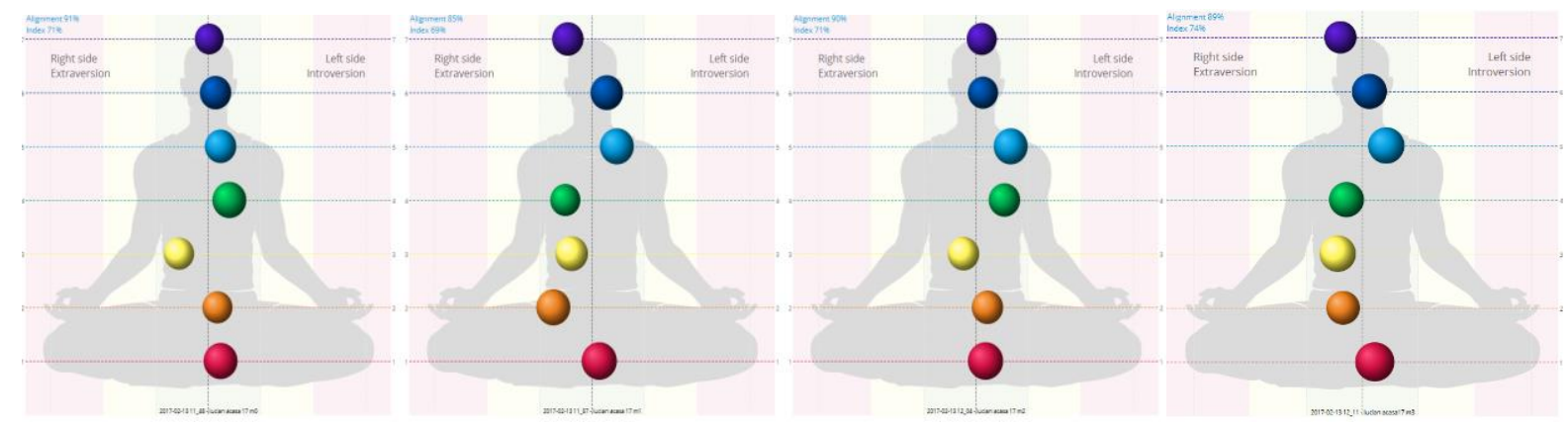

Figure 2.The sevens energy centers position for the first four measurements (The article's first author) 
The next image, Figure 3, presents in terms of emotional pressure, energy, general symmetry and organ balance the state of the first author of the article. Beginning with the second measurement, the intention of the subject to change his state became present and, as a consequence, the emotional pressure began to grow.

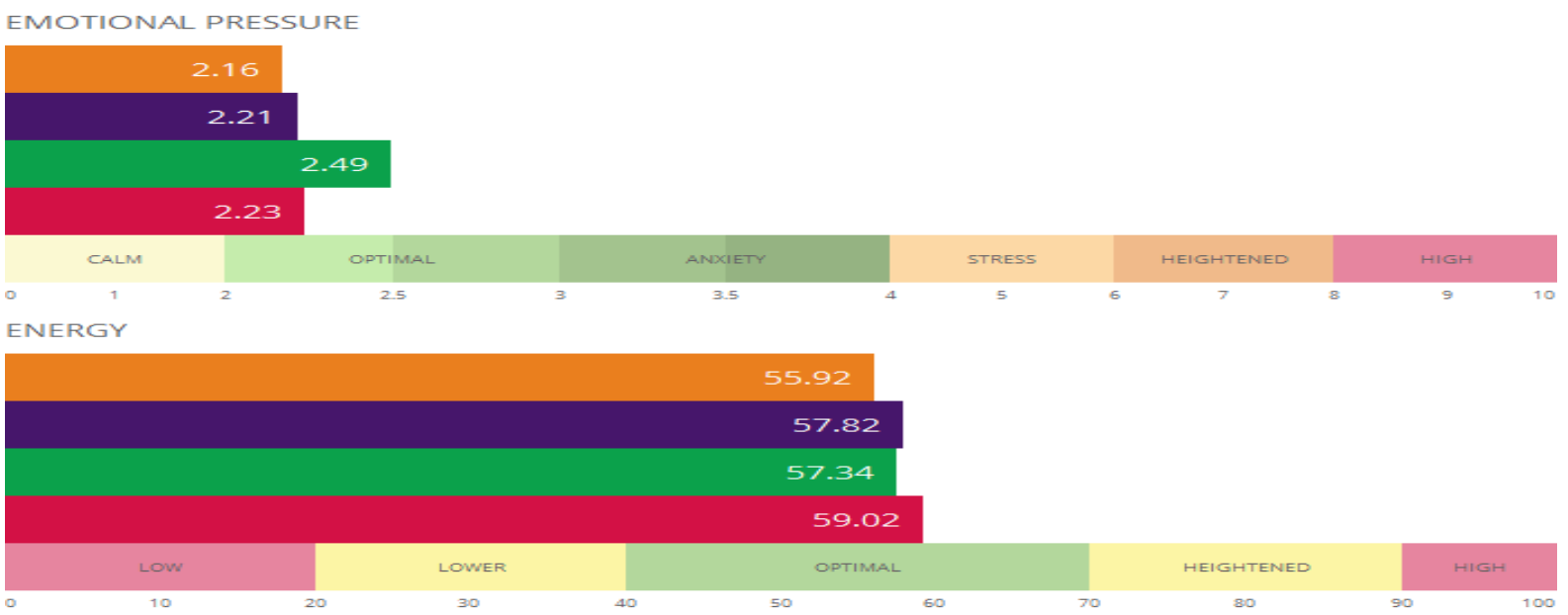

LR SYMMETRY

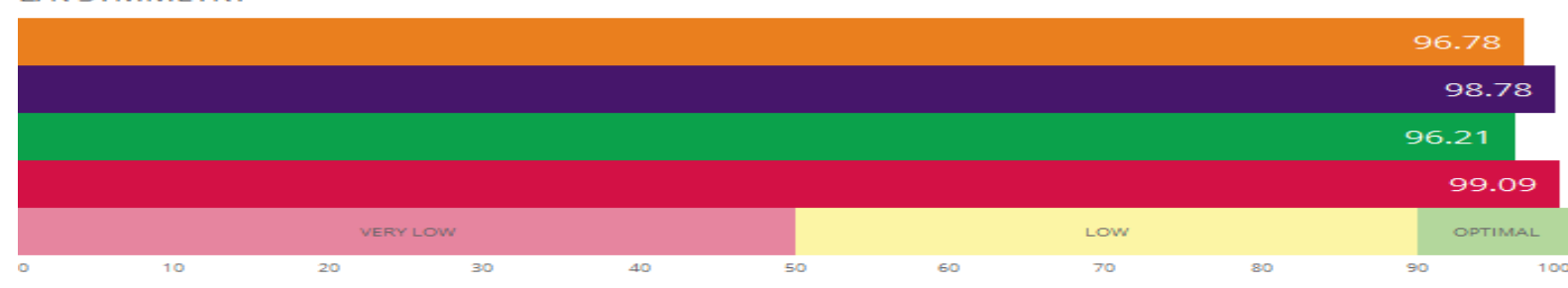

ORGANS BALANCE

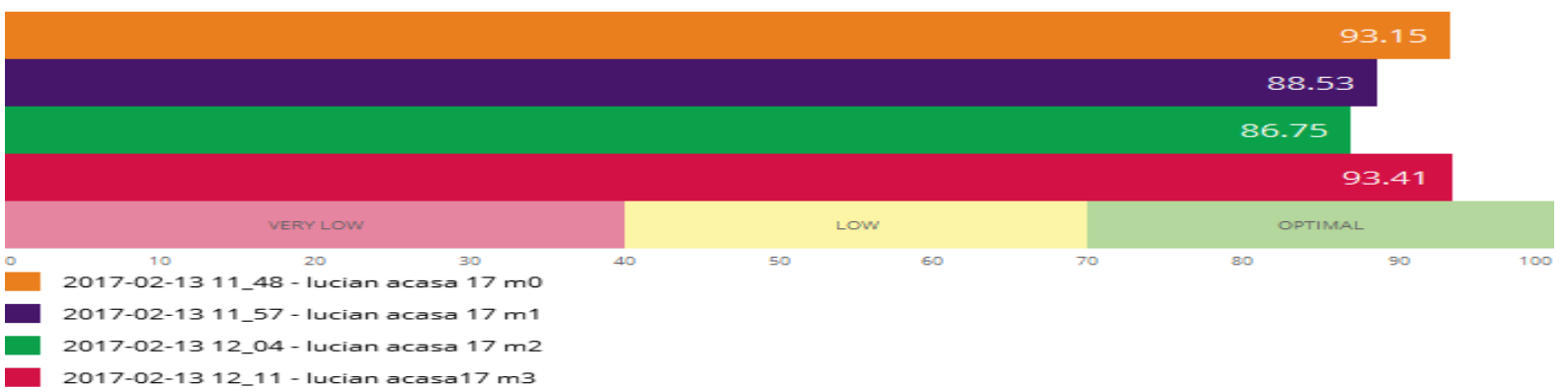

Figure 3.The emotional pressure, energy, symmetry and organ balance of the article's first author for the first four measurements, February 2017 (The article's first author)

PICBE | 280

Source: Authors' own research

The energy is also rising, reaching a value of 59.02 from 100 at the end of the measurements. The symmetry is growing as well, reaching $99.09 \%$ for the fourth measurement. The organ balance has a small improvement, too, at the end with a value of $93.41 \%$. All these things happened between hours $11 \_48$ and $12 \_11$, as it is mentioned at the left bottom of Figure 3.

As we can see, all the parameters are in the optimal zone, with a general balance higher than 99\%. We just showed that the original method applied by the subject can give very good results which can be maintained in time in order to have a good health and also a good physical and psychic state. This procedure usually requires some minutes to reach a very good symmetry, which means over $99 \%$, as can be seen from the last measurement in Figure 3. The general balance of the body is also shown in Figure 4. 

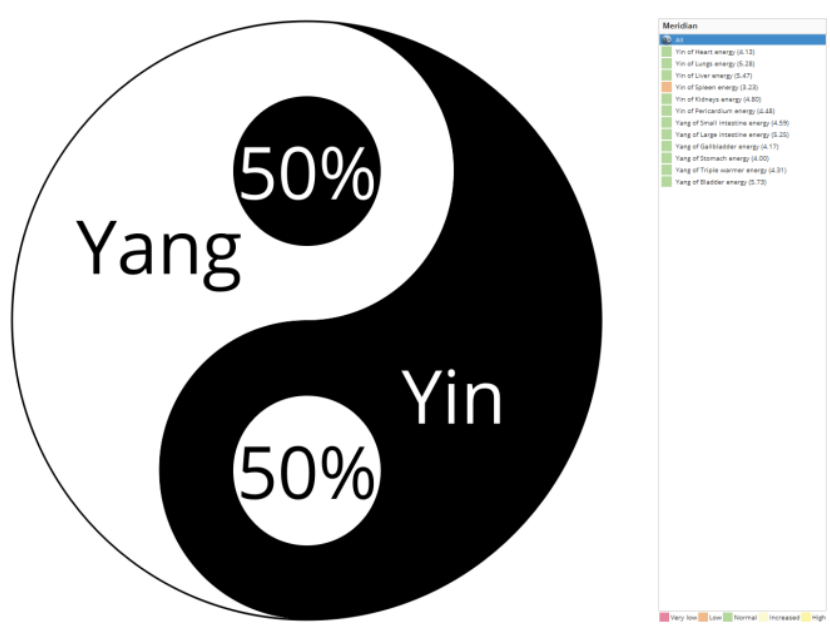

PICBE | 281

Figure 4.The general symmetry or balance for the measurement number 4. (The article's first author)

Source: Authors' own research

Here, we can see the equilibrium between the Yin and Yang of the subject. Yin and yang is a relational and complex concept in the Chinese culture. It was improved and developed during a long period of time. The two opposing and complementary principles of the cosmic energy form a cosmic duality that can be observed everywhere. Yin is a feminine energy which is negative, dark and still. Yang is a masculine energy which is positive, bright and hot. They are inward and outward energies.

They complement each other, their sum being in our case of the Bio Well Device $100 \%$ at the end. The opposite forces that coexist in every living being can change in intensity and, as a consequence, the yin and yang will change. For the Chinese, these religious concepts represent the primordial forces which make up the universe and its components. The balance of the yin and yang is very important. If the yin grows then the yang will decrease and vice versa. The interchange of the yin and yang is continuous. The balance of the yin and yang exists in everything. The yin-yang symbol, also known as the Tai Chi symbol, is shown in Figure 4. The yin zone is black and its percentage is written in the dark zone, the yang is white and its percentage is written in the white zone. Their combination is represented as a circle which is divided into two halves by an S curved line.

The authors will show in this article that the human being can have control even on the percentages of the yin and yang and that these can be changed at the will of the analyzed subject. The percentages of the yin and yang depend practically on the energy center number 1 position, represented as a red disk in Figure 5.

\section{The last two measurements and results}

For the second part of the article, the authors took the last measurement of the previous four. Together with measurements number 5 and 6, Figure 5 is designed, so as to make a comparison starting from the last emotional pressure of 2.23 and the last symmetry of 99.09\%. 


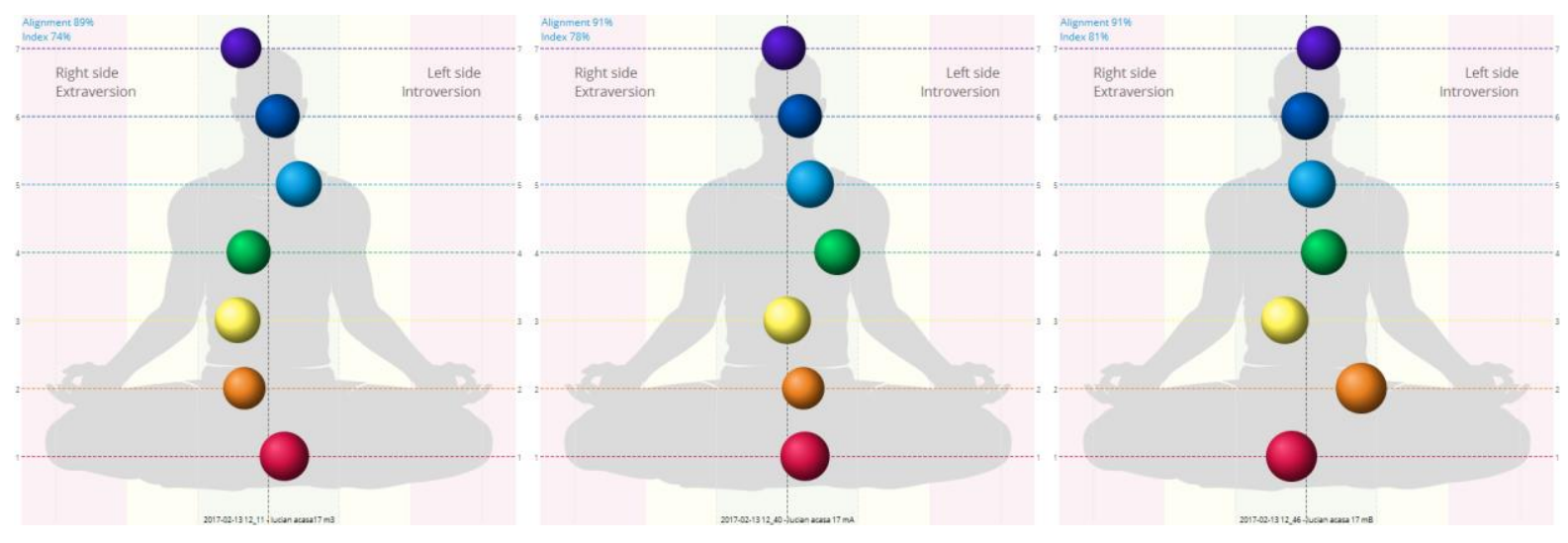

PICBE $\mid 282$

Figure 5.The seven energy centers position for the measurements number 5 and 6 , compared with the last measurement from Figure 1, right position.

(The article's first author)

Source: Authors' own research

The last two measurements, with reference to the measurement number 4, situated on the left in Figure 5, prove that a significant displacement of the center number 1 , in red, can be obtained. The subject acts by his will to increase the yang percent at the beginning from $50 \%$ to $52 \%$. This thing is done using only his will and with the subject standing motionless.

That signifies we have a modification of a total of $4 \%$ between the yin and yang during a short period of time. It is depicted in the central position from Figure 5 and also in Figure 6, with the help of the two percentages.
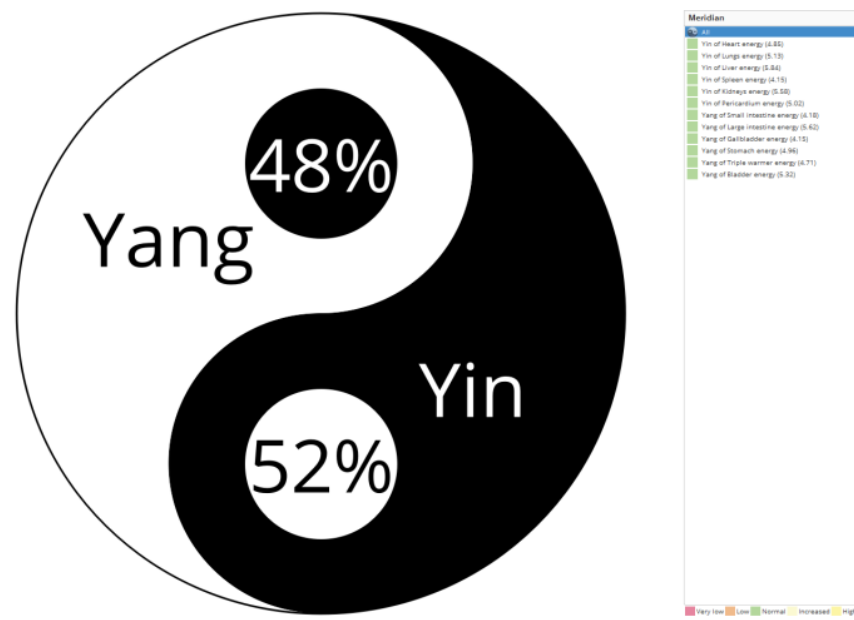

Figure 6.The general symmetry or balance for the measurement number 5. (The article's first author)

Source: Authors' own research

As we can see in Figure 8 the effort to increase the yang is accompanied by a small increase of the emotional pressure and of the energy. The emotional pressure grew from 2.23 to 2.33 and the energy from 59.02 to 60.32 .

Because the intention of the subject is focused only on the energy center number 1 , the symmetry diminished from $99.09 \%$ to $98.22 \%$ and also the organ balance from 93.41\% to $91.86 \%$.

The subject acts again and in the same manner, thus increasing the yang percent from $52 \%$ to $54 \%$, this time after 6 minutes, as shown at the bottom of Figure 8 , the left part. That signifies we have a modification of the symmetry with another $4 \%$. 
The movement of the first energy center colored in red is depicted in the last position from Figure 5, on the right. The total modification of the symmetry is presented in Figure 7.
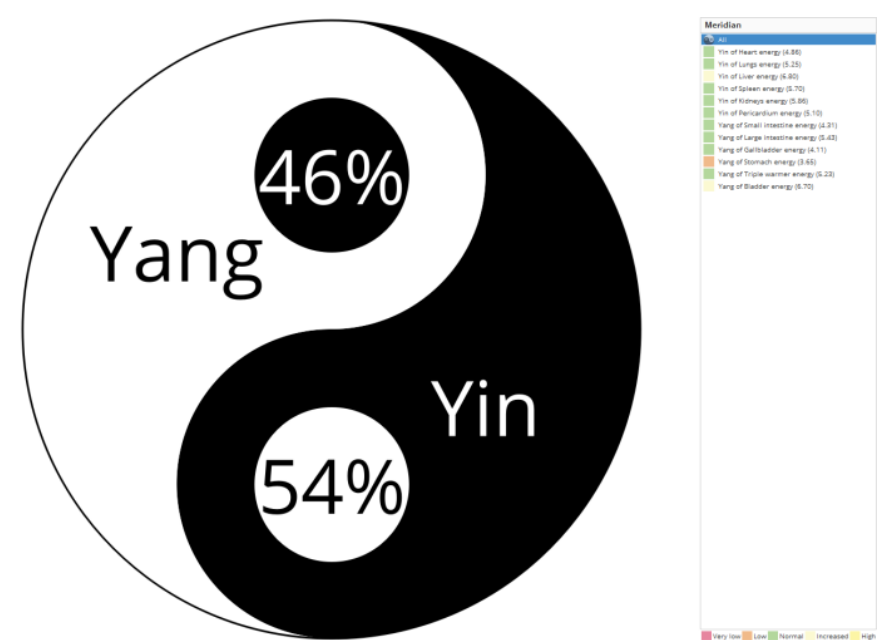

PICBE $\mid 283$

Figure 7.The general symmetry or balance for the measurement number 6 (The article's first author)

Source: Authors' own research

The emotional pressure grew again from 2.33 to 2.64 , as pointed out in Figure 8. As a consequence of the interior effort, the energy grew again, from 60.32 to 61.88 .

The intention of the subject is focused again only on the energy center number 1 , therefore the symmetry diminishes from $98.22 \%$ to $97.75 \%$ and this time the organ balance grows a little from $91.86 \%$ to $92.41 \%$.

The total variation of the subject emotional pressure is of $26.4 \%$. A consistent effort had to be done to have $8 \%$ difference between the yin and yang.

The variations of the emotional pressure, energy, left/right symmetry and organs balance of the measurements number 5 and 6 compared with the last measurement from the first set of four measurements can be seen in Figure 8.

Again, all the parameters are in the optimal zone which shows the continuous concern of the subject to take care of his general state and of his health.

The yin and yang cannot remain fixed; they will change continuously because they are in a dialectical symbiosis [Dumitrescu \& Constantin, 1977]. 


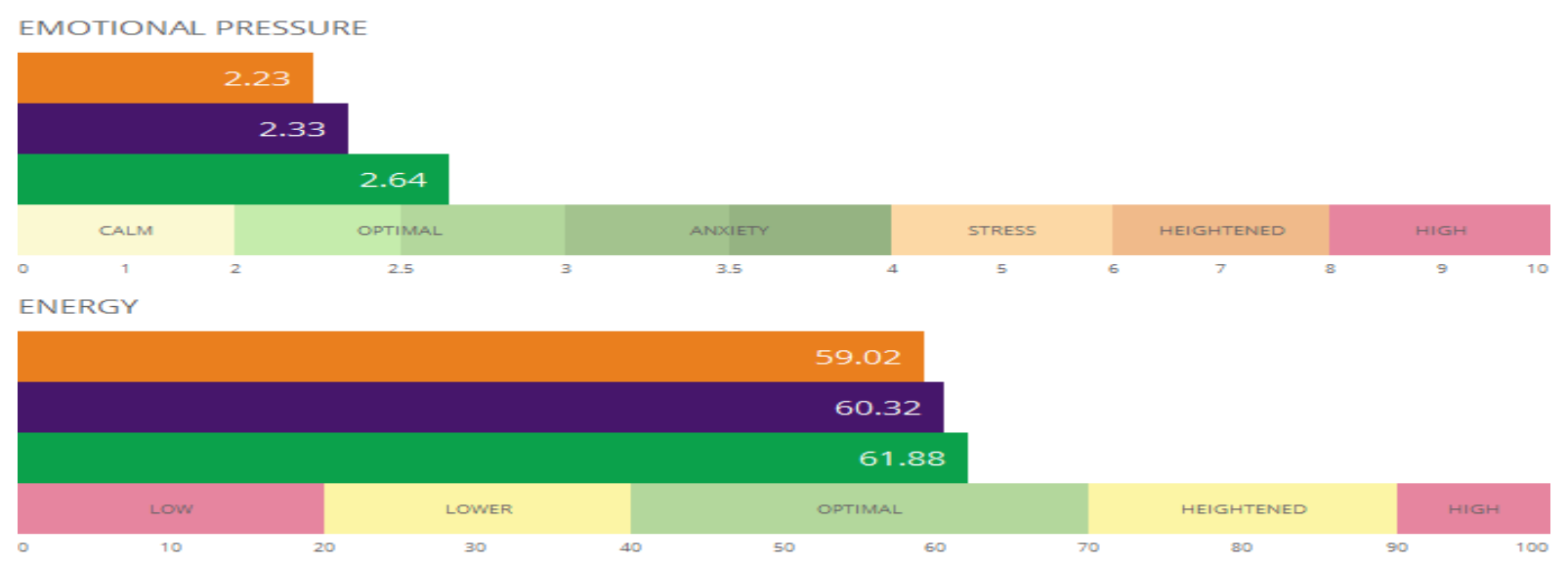

PICBE | 284

L/R SYMMETRY

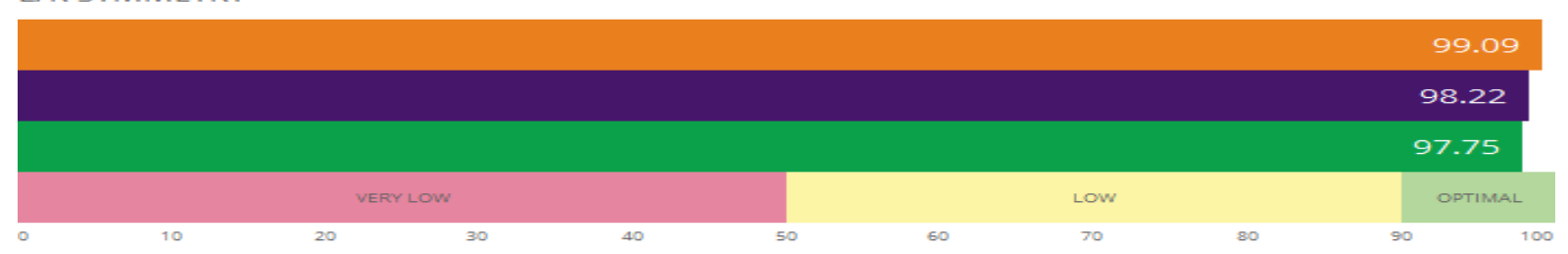

ORGANS BALANCE

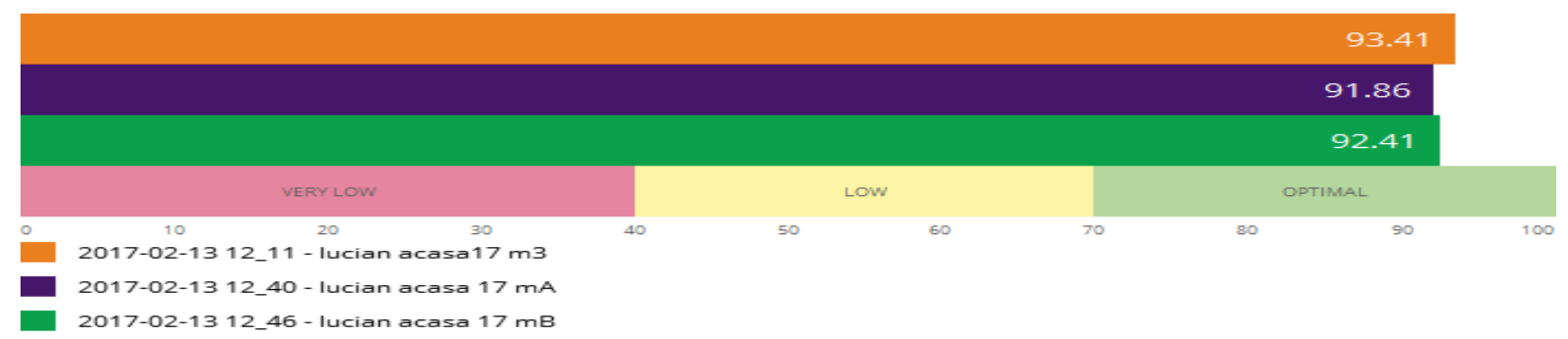

Figure 8.The emotional pressure, energy, symmetry and organ balance of the article's first author for the measurements number 5 and 6, compared with the last measurement from Fig. 2 , color orange (The article's first author)

Source: Authors' own research

\section{Conclusions}

The authors proved that using a special technique called "The method of the stretched wire slowly", very good results can be obtained in terms of symmetry and, also, the organs symmetry of a human being. These very good results can extend at the level of the human being energy and even at a normal level of the emotional pressure.

We can easily get accustomed with this method and its favorable effects can be preventive and applicable, so as to maintain a general good health. This method can be applied by every businessman in every corner of the world, anytime, with zero costs.

The authors also showed that a direct intervention can be made at the level of the energy centers by the own will of the subject. In the present case we speak about the energy center number 1 . Significant displacement can be made with the help of thoughts and not only, at the level of this center. If last year the authors proved that the position of the second energy center can be changed at the will of the subject [Mândrea et al., 2018], this year they show the same thing about the energy center number 1 . A future wish of the authors is to show that centers number 3 to 7 can also be moved. The movement of the other centers, 3 to 7 , is confirmed by behaviors, but not yet by measurements. If all the centers can be moved, then everything can be done. 
Referring to the second part of the article, any change in the harmony between the yin and yang determine a recovery reaction, which has the tendency to reestablish the balance. Looking this was, the illness appears first of all as a disbalance between these forces/principles yin and yang. For this reason, maintaining the balance, or in case of misbalance, the recovery at the situation of equilibrium is especially important, because it does not give time to the illness to settle. Even in this worse case, the equilibrium recovery and harmony lead to a quick recovery. "The stretched wire slowly method" represents an easy way to obtain the energy centers alignment which balance the whole energy of the body.

The GDV devices offer synoptic images and hence they are very useful in following the results of the energetic balance methods. With this occasion we are grateful to all the previous researchers that contributed to the final making of the Bio Well Device [Motoyama, 2009], [Lupeanu, 2008], [Becker \& Selden, 1985], [IonescuTârgoviște, 1986], Dobson \& O’Keffe, 2000], [Guja, 2008], [Guja, 2000,a], [Guja, 2000,b], [Guja, 1993], [Dumitrescu, 1979], [Yakovleva, \& Korotkov, 2013], [Korotkov, 2014].

As we know, the things presented before were not done until now by other subjects and researchers. As a consequence, the general symmetry and the organ balance are affected as we can see in Figure 8, but we can also see that their levels are still in the normal zone. The general state of health is not affected and this also means that the subject cannot be anxious or stressed.

All the knowledge of some predecessors [Mandel, 1986], [Moss, 1979], [Kim, 2002], [Korotkov, 1999], [Popp, 1998], [Popp et al., 1992], [Rubik, 2002a], [Rubik, $2002 \mathrm{~b}$ ] was used by the first author of this article to get the abilities to succeed in making the present measurements.

All the measurements could be made due to the capacity of the article's first author to determine his body to respond very quickly to his own intentions and will. The authors consider that the good results of this experiment are a stimulus to continue the studies referring to the human being energy. All that we showed before can help anyone to be a successful person in business and also in life.

\section{References}

Becker, R., Selden, G. (1985) The Body Electric, Electromagnetism and the Foundation of Life, Morrow Publishing House, NY, 1985.

Curta, I. (2014) Measurements of the Human Body Parameters Made with the GDV Camera and the SCIO Device to the influence of Colloidal Silver Solution, International Conference OPTIROB 2014.

Dobson P., O'Keffe E. (2000) Investigations into Stress and it's Management using the Gas Discharge Visualization Technique, International Journal of Alternative and Complementary Medicine, June 2000.

Dumitrescu I.F., Constantin D. (1977) "Acupunctura științifică modernă", "Modern Scientifically Acupuncture", Editura Junimea , Junimea Publishing House, Iași.

Dumitrescu, I.F. (1979) Electronografia - Metode electronografice în biologie, Electronography - Electronographic Methods in Biology, Editura Ştiinţifică şi Enciclopedică, Scientific and Encyclopedic Publishing House, Bucharest.

Guja, C. (2008) Antropologie Informaţională, Informational Anthropology, Editura Academiei, Academy Publishing House.

Guja, C. (2000, a) Aurele Corpurilor. Interfețe cu Cosmosul, The Body's Aura, Cosmos Interfaces, Vol. II, Editura Polirom, Polirom Publishing House, Iaşi, ISBN 973-683394-1. 
Guja, C. (2000, b) Aura Corpului Uman. Introducere în antropologia individului, The Human Body's Aura, Introduction in the Individual Anthropology, Editura Polirom, Polirom Publishing House, Iaşi, ISBN 973-683-394-1.

Guja, C. (1993) Aurele Corpurilor. Interfeţe cu Cosmosul, The Body's Aura, Cosmos Interfaces, Vol. I, Editura Enciclopedică, Encyclopedic Publishing House, Bucharest, ISBN 973-45-0050-3.

Ionescu-Târgoviște, C. (1986) Acupunctura şi bioenergetica umană, Acupuncture and Human Bio-Energy, Editura Sport Turism, Sport Turism Publishing House.

Facultatea de Medicină şi Farmacie Oradea, Medicine and Pharmacy Faculty Oradea.

Kim T.J. et al. (2002) Bio-photon emission from fingernails and fingerprints of living human subjects, Acupuncture Electrotherapy Res. 27:85.

Klaus H., Miceal L. (November 6, 2007) The Orb Project, Paperback - Deckle Edge. Meg Blackburn Losey, Magnificent Orbs, spiritlite.com.

Korotkov K. (1999) Aura and consciousness, St Petersburg, Russia, Russian Ministry of Culture, State Editing and Publishing Unit.

Korotkov, K. (2002) Human Energy Field, Study with GDV Bio-Electronography, Backbone Publishing Company, NJ, USA, ISBN 096443119X.

Korotkov, K. (2012) Energy fields: Electro-photonic analysis in humans and nature, E-book: Amazon.com, pg. 1-240.

Korotkov, K. G. (2014) Energy Fields Electro-Photonic Analysis in Humans and Nature. $2^{\text {nd }}$ Edition, Create Space Independent Publishing Platform, April 21.

Lupeanu, A. (2008) Corelaţii între potenţialele bio-electrice, structurile neurovasculare si zonele punctelor de acupunctură reflectate în eficienţa terapeutică a acestor locaţii, The Correlations between the Bio-Electric Potentials, Neurovascular Structures and the Puncture Zones of the Acupuncture reflected in the Therapeutical Efficiency of these Locations, Teză de doctorat, PhD. Thesis.

Mandel P. (1986) Energy emission analysis: new application of Kirlian photography for holistic medicine, Berlin, Synthesis Publishing.

Mândrea, L. (2011) Comportamentul sufletului în corpul uman, The Behaviour of the Soul in the Human Body, Editura Tornada, Tornada Publishing House, Bucharest 2011.

Mândrea, L. (2014) Percepții extrasenzoriale, Sufletul în corpul uman, Extra-sensorial Perceptions, The Soul in the Human Body, Editura Tornada, Tornada Publishing House, Bucharest 2014.

Mândrea, L., Costea, M., Torp, A. (2015) The Energy Emissions Produced by the Human Being and their Practical Use, THE 9th INTERNATIONAL SYMPOSIUM ON ADVANCED TOPICS IN ELECTRICAL ENGINEERING, May 7-9, 2015, Bucharest, Romania, 978-1-4799-7514-3/15/\$31.00 (C2015 IEEE, P.260-264.

Mândrea, L., Torp A. (2016) Energia umană și posibilități de remediere proprii, Human Energy and Self Remedy Possibilities, EUB International Conference, April 4-5, Bucharest, Romania.

Mândrea, L., Chirilă, A. (2017) The Complete Human Being, Energy and Soul, Proceedings of the International Conference on Business Excellence, published by De Gruyter Open, 2017-08-26, DOI: https://doi.org/10.1515/picbe-2017-0046, pp. 427-436, Volume 11, Issue 1, ISSN 2558-9652.

Mândrea, L., Chirilă, A. (2017) The Complete Human Being, Energy and Soul, the $11^{\text {th }}$ International Conference on Business Excellence, Strategies, Complexity and Energy in Changing Times, 30-31 March 2017, Bucharest, Romania. 
Mândrea, L., Curta I. (2017) The modification of the energy level of the human being, Influences on the psychic state and health, A XVII-a Conferință internațională multidisciplinară "Profesorul Dorin PAVEL - fondatorul hidroenergeticii românești”, Sebeș-Alba, 2-3 iunie 2017, pg. 117-124, ISSN 2067-7138.

Mândrea, L., Curta I., Marosy Z. (2018) High Energy, Increased Balance and Self Control, Necessary Conditions for Performance and a Good Health, The 12-th International Conference on Business Excellence, Innovation and Sustainability in a Turbulent Economic Environment, 22-23 march 2018, Bucharest, Romania.

Moss T. (1979) The body electric: a personal journey into the mysteries of parapsychological research, bioenergy and Kirlian photography, Los Angeles, Calif, JP Tarcher.

Motoyama, H. (2009) Teorii despre Sistemul Chakrelor, Theories about the Chakras System, Editura Excalibur, Excalibur Publishing House, Bucharest, ISBN 978-9731930-22-0.

Popp F.A. (1998) Electromagnetic bio-information, New York City, Springer Verlag.

Popp F.A., Li K.H., Gu Q. (1992): Recent advances in bio-photon research and its applications, Singapore and New York, World Scientific Publishing.

Rubik B. (2002 a) Scientific Analysis of the Human Aura, In Heinze R.I., editor: Proceedings of the 18th International Conference on the Study of Shamanism and Alternative Modes of Healing. Santa Sabina Center, Dominican University, San Raphael, September 1-3.

Rubik B. (2002 b) The bio field hypothesis: its biophysical basis and role in medicine, J Alternative Complement Med. 8(6):703, 2002b.

Yakovleva, E., Korotkov, K. G. (2013) Electro-Photonic Analysis in Medicine. GDV Bioelectro-graph Research, ISBN 978-1481932981.

https://www.britannica.com/topic/yinyang

https://ro.wikipedia.org/wiki/Ayurveda

https://en.wikipedia.org/wiki/Muladhara 